\title{
Foresighting Economic Spillovers Towards Transformative Change
}

\author{
Mohamed Buheji \\ International Inspiration Economy Project- Bahrain \\ Email: buhejim@gmail.com
}

Received: December 26, 2019 Accepted: January 8, 2020 Published: February 18, 2020

doi:10.5296/iss.v8i1. URL: http://dx.doi.org/10.5296/iss.v8i1.

\begin{abstract}
This paper critically reviews the challenges and the opportunities that economic spillovers bring to different sectors. The purpose is to investigate how such spillover could be utilised for the benefit of slow-developing countries as Africa and the Middle East. The work of Karlsson et al. (2018) is used as the main reference for this study.

The outcome of this study shows the importance of having the proper strategies, policies and the right clusters that support the positive exposure of the spillovers as per the country's competitiveness advantage or needs. This work would have a further implication on the decision-makers and governments that are trying to re-invent their countries economic resources and boost its limited productivity.
\end{abstract}

Keywords: Economic Spillovers, Industrial Transformation, Economic Development, Knowledge-Economy, Inspiration Economy, Future Foresight 


\section{MIN Macrothink}

\section{Introduction}

This paper explores the different types of economic spillovers as a consequence of globalisation. Today, we see many countries are benefiting from the ideas and the knowledge which are moving at the speed of thought across national borders and generating international spillovers. These spillovers are influencing the countries and communities to be of interdisciplinary-based approaches which are helping to bring more original structural changes. Quella (2007).

Globalisation is causing businesses and sectors to be interdependent on differentiation inputs as human capital, creativity, innovation and networks. As if they working all together based on collaboration and sharing economy models. Buheji and Ahmed (2018a, b), Battu et al. (2004).

The following critical review focuses on how globalisation is influencing the economic spillover in different sectors. Then the types of spillovers and its related distances and pools are explored. Spillovers of knowledge, technology, human capital and education are identified, followed by examples of the pools and distances. Buyer-supplier chain and exposure to spillovers are discussed to see their influence on production inputs. The role of industrial policies in the spillover effect is final reviewed, along with the possible negative sides of economic spillovers. Buheji (2019).

\section{Critical Literature Review}

\subsection{Definition of Spillover}

In economics, a spillover is an economic event that occurs due to the existence of seemingly unrelated context. For example, new technology has a positive spillover effect in countless fields. While the use of chemical pesticides in farming is a negative spillover upon neighbouring organic farms. While taking care of the beauty of the small household flower gardens has a positive spillover effect upon the local tourism industry.

The economic development of the ASEAN (Association of South-East Asian Nations) increased the trade and the spillover effects on the industrial capacity of these countries and influenced their labour sector. This influenced the capacity vs demand of the participating small and medium enterprises. This may be one of the reasons that triggered the researcher interest in the concept of spillover, as it meets one of the fundamentals of inspiration economy, that is to transform many sectors of the economy and the socio-economy to work on the concept of 'capacity vs demand', rather than the capital-based formula 'supply vs demand'. Li and Martin (2017).

With the positive spillovers from research to knowledge capital, the growth rate of the economy is constant in the steady-state.

\subsection{Globalisation and Economic Spillovers}

Despite its negative sides, one has to admit that the phenomena of globalisation are considered to be the main drivers of economic spillovers which are influencing many recently 
sectoral changes induced by the world economy in the last three decades specifically, Li and Martin (2017). For example, the ICT transformed revolution influenced how the information created in all types of industries and created more rapid spillovers in an interconnected way in all over the world. Buheji (2019).

Karksson et al. (2018) emphasised that global integration brings greater market-based trade that leads to financial flows which in the end lead to institutional harmonisation. Global integration causes the existence of spillover factors which lead to technological progress, reduced cost of physical spatial interactions; and removal barriers to the flows of trade.

The trend towards global integration implies that news, information, ideas, knowledge, creativity, will spillover at an increasing speed and reach more destination increasingly. These rapid spillovers affect increasingly larger parts of the world and this influence rapid structural changes at both national and regional level.

\subsection{Types of Spillovers and its related Distances and Pools}

There are different types of spillovers (e.g. knowledge spillovers, technological spillovers, education and skill spillovers). These spillovers can be measured in depth by their capacity to eliminate the various distances. For example, what would be the extent of the technological distance in the supply chain? In the same time, we have pools that help to ease the flow of the spillovers and prepare its potential sources.

\subsubsection{Knowledge Spillovers}

Knowledge spillover happens when products and services can be produced by other human capital, or when a neighbouring community or country could benefit from the development of the knowledge originator. Quella (2007).

Today machine tools as 3D printers are considered part of the spillover, which is creating creative destruction that transforms the economy and enhances the exposure of innovation spillovers. All a result, the type of labour productivity would help to bring higher pay for those of low and medium skill hours. Buheji and Ahmed (2018a, b).

Exposure to education spillovers managed to also bring positive effect on the size of the spillover coefficient of innovation and improved the innovation activity of supplying sectors, where the weights are the relative amounts of inputs purchased from those sectors. Monjon and Waelbrock (2003).

\subsubsection{Technological Spillovers}

When technological spillover occurs, new or developed products will make the other sector to innovate based on this development. This spillover even doesn't require the other community or other countries to realise all the technical knowledge by the originator fully, but it still could develop products and services that would complement this development. Buheji and Ahmed (2018a, b).

Technological spills might lead to inventions across other disciplines and even other technological domains. 


\subsubsection{Human Capital and Education Spillovers}

Human capital spillovers are highly related to growth theories that are concerned with the accumulation (or "flow") of human capital and the other with the stock of human capital. Once spillover of human capital occurs, it would influence education, which raises the level of the human capital again and affect their output. Battu et al. (2004).

Human capital and education bring in nine types of economic and non-economic spillovers that result from improvements in education. These spillovers are represented by the variety of income gains. The research and development raise productivity in other disciplines too and then create even employment-related spillovers.

\subsection{Pools of Spillovers}

Any economic spillover requires pools. These pools are mainly knowledge pools and are usually external to the firm or the community or the country. In this pool, the beneficiaries could withdraw or even combine internal knowledge with external ones to improve their productivity and differentiation.

Through pools, any beneficiary would have a higher probability to access sources of spillovers and to benefit from its outcome. These pools bring innovation sources and thus could be available for either incremental or radical transformations. Bosworth (2014).

\subsection{Distance of Spillovers}

Spillover distance can be sometimes important and sometimes destructive. For example, technological or research and development distances are sometimes crucial when the organisations working in similar or overlapping areas of technology are more likely to benefit from each other's research findings regardless of their outcome results.

Spatial distance appears destructive when organisations located further apart less likely to benefit from spillovers, even if they work in the same area of technology. Cultural distance also could help to prevent the benefit from spillovers, and even prevent foreign investment.

Organisations within the same sector should be equally exposed to benefiting from the pool other hidden distances are preventing them from benefiting from the size of each of these spillover pools. Li and Martin (2017).

\subsection{Buyer-Supplier Chain and Exposure to Spillovers}

The level of exposure to spillovers depends on the design of the supply chain and what is the level of influence it could have on the transmitting spillovers. The magnitude of such exposure, particularly in terms of $\mathrm{R} \& \mathrm{D}$ and educational spillovers, could affect the organisations' performance and innovation.

The buying sector benefits from the innovation brought in the quality of products and the reduction in costs. Countries with high exposure ratios have higher input-output efficiency in spillovers generation, which give them a greater competitive advantage. Bosworth (2014). 


\subsection{Spillover Influence on Production Inputs}

Spillover found to positively influence the speed, the availability, the capacity, the price of many industries. Spillover works in lowering the costs of coordinating economic activities over long distances which helps to produce different cost and profit centres for different tasks.

Spillover causes physical and spatial interaction. Thus, we found that as a result of the spillover containerisation have developed further in the shipping industry and led to a greater capacity for transportation of items in more safe and efficient ways. The shipping time for goods between the globe on average reduced by 50\%. This spillover also influenced the insurance sector, which managed to reduce its cost and included the insurance on shipping transit. This spilt-over to dock workers productivity which improved by 15 times which in the end led to the reduction of the total cost of shipping by 20 times. Buheji (2019).

The reduction of the total cost of shipping spilt-over to reduce the share of retail prices and reduced the cost of transport from $10 \%$ to $1.5 \%$. This led to the expansion of the global air traffic system and the decline in air transport cost. This spillover led to greater mobility of workers, particularly knowledge-handlers

Transport technology reduced transport times and transport cost and contributed to more integrated works and projects. This reduced the trading cost and brought faster shipping and established supply chain that spilt to value chains. The growth of global flows of goods, services, labour and capital led to more organisational changes influenced by the differentiated value chains. This led to greater economic integration and reduced the tariff rates by more than $50 \%$ in many developed and higher developing countries.

Economic and financial integration along with ICT revolution induced growth of global value chains which led to better-integrated production. Kierzkowski (2001) introduced a model which induces a realignment of the production patterns among countries. The Kierzkowski model focuses on capturing the differences in technology and the factor of productivity. This model links services from separate locations around the world to play a role in various production stages or segments.

\subsection{Role of Industrial Policies in Spillover Effect}

Industrial policy shapes today and the future found to play important role patterns in the global production efficiency and output. Today Mexico is the manufacturing hub for US cars, electronics and textiles to save labour cost. This spillover demand increases Mexico total employment to $20 \%$. This idea led to the emergence of special economic zones in China.

Industrial policies can influence, therefore, exports. Export can lead to developments in human capital, similar to the case in Asian countries where the technical manufacturing demand in the region led to spillover on engineering education in these countries. Monjon and Waelbrock (2003). 


\subsection{The Negative Side of Economic Spillovers}

Similar to its positive impact, spillovers also have a strong negative impact on different business sectors, especially during great recessions. The sectoral shocks create variability and instability in industries productions. The size of the shock creates another direct and indirect spillover impact with other sectors. Li and Martin (2017).

The first wave of spillover might hit the quality of the overall production and R\&D activities. Here, the scarcity of knowledge spillovers in a particular industry can reduce the capacity of its employees at all stages and levels and reduce the maturity of productive experience. This negative spillover effects the Labour-led knowledge and the mechanics of their learning process. Quella (2007).

\section{Discussion and Concluding Remarks}

This paper focused on the comprehensive review of the economic spillovers and their importance to the economies and socio-economic development. The work of Karlsson et. Al (2018) found to be a good reference for researchers who are concerned about means, strategies and clusters for economic development. From the literature reviewed besides the Karlsson team edited book, we find that countries can work on foresight better future if they read the development streams and the value chains of the different sectors, besides utilising their demographic and geographic location. Besides, countries policymakers can be advance their capacity to attract investors if they understand the flow of spillovers and what are the potential differentiation they could optimise to their either pools or distances. Here are the main two main implications of this review:

\subsection{Better Foresighting of Future Spillovers}

Origin and destination of knowledge spillovers can impact many series of macroeconomic sectors and industries. Industries as manufacturing, logistics, transportation, services and trade are highly interconnected. Therefore, they have inter-sectoral knowledge spillovers to different sectors of the economy and in different periods.

Most of these spillovers also have a mix of embodied generating inputs as labour and technology flows that both create a good proxy for knowledge spillovers. This creates models with inter- and intra-industry labour-generated knowledge spillovers which bring in optimal market solutions in terms of resource allocation.

Mix spillovers develop more with geographical proximity. It starts with productive stages that benefit the labour-generated knowledge spillovers. Such inter-sectoral knowledge spillovers are particularly important in the service sector such as trade, transport and communication industries.

The time dimension is very important when spillovers could create innovations that could be reflected in consumer goods. If innovation transformed in the right time, it could bring more proper R\&D spillovers which transform 'ideas' into profit margins. 


\subsection{Spillovers and Investment Decisions}

Identifying the type of spillovers and their pools besides distances should part of the investors' package plans of the economic development board. Surely, many developing and even under-developed countries can benefit from this thinking to set the government policies with clear decision-making intentions towards seeing the potential coming positive spillovers and what needs to be invested in.

Therefore, spillovers could help in raising the capacity and the drive towards investments optimisation in areas as R\&D and innovation. The ability to focus on spillovers opens up new areas of interest, such as the supply chain.

\subsection{Final Words}

The limitation of this research is that it is based on one main reference book, besides selective of recent references. However, this work is meant to give a general review about spillovers in simple language to encourage decision-makers to take proper decisions to attract the proper industry suitable for the country's condition and foresighted future.

This paper opens up many potential kinds of research about spillover phenomena in different economies, i.e. similar to socio-economic spillover or creative economy spillover which are not addressed in the literature. Having such research would help to develop better foresight of what future we can develop for our countries and the rest of the world. Also, this work would help fewer developing countries and communities to think differently about their positioning and how to capitalise on specific conditions to raise their capacity compared to the world or region demand.

\section{References}

Battu, H., Belfield, C. R., \& Sloane, P. J. (2004). Human Capital Spillovers in the Workplace: Evidence for the Service Sector in Britain. International Journal of Manpower, 25(1), 123-138. https://doi.org/10.1108/01437720410525036

Bosworth, D. L. (2014). Estimating Innovation Spillovers: An International Sectoral and UK Enterprise Study Technical Annex. Department for Business Innovation and Skills, London.

Buheji, M. (2019). Industrial Relations in Emerging Economies, A book Review. American Journal of Economics, 9(1), 21-22.

Buheji, M., \& Ahmed, D. (2018a) Book Review- Innovation in Developing and Transition Countries - New Horizons in Regional Science Series. Review of European Studies, 10(3). https://doi.org/10.5539/res.v10n3p55

Buheji, M., \& Ahmed, D. (2018b). Book Review - Capturing the Innovation Opportunity Space Creating Business Models with New Forms of Innovation. International Journal of Inspiration \& Resilience Economy, 2(1), 30-30.

Department for Business, Innovation and Skills. (2014). Estimating Innovation Spillovers: An International Sectoral and UK Enterprise Study. BIS Research Paper Number 178. Retrieved 
from http://www.nationalarchives.gov.uk/doc/open-government-licence

Karlsson, C., Cornett, A., \& Wallin, T. (2018). Globalisation, International Spillovers and Sectoral Changes Implications for Regions and Industries. New Horizons in Regional Science series, E-Elgar. https://doi.org/10.4337/9781786432483

Li, N., \& Martin, V. (2017). Real Sectoral Spillovers: A Dynamic Factor Analysis of the Great Recession. International Monetary Fund, University of Melbourne, February 13.

Monjon, S., \& Waelbrock, P. (2003) Assessing Spillovers from Universities to Firms: Evidence from French Firm-Level Data. International Journal of Industrial Organization, 21, 1255-70. https://doi.org/10.1016/S0167-7187(03)00082-1

Quella, N. (2007). Intra- and Inter-Sectoral Knowledge Spillovers and TFP Growth Rates Instituto Tecnológico Autónomo de México (ITAM) April. Retrieved from https://mpra.ub.uni-muenchen.de/2853/1/MPRA_paper_2853.pdf

\section{Copyright Disclaimer}

Copyright for this article is retained by the author(s), with first publication rights granted to the journal.

This is an open-access article distributed under the terms and conditions of the Creative Commons Attribution license (http://creativecommons.org/licenses/by/3.0/). 